\title{
Protective Effect Of Ascorbic Acid On Cisplatin Genotoxicity In Male Mice Bone Marrow Cells
}

\author{
Nada, H.A. Al- Twaty \\ Department of Biology, King Abdelaziz Universiy
}

\begin{abstract}
Cisplatin (cis-diamminedichloroplatinum II) is an effective antitumor agent with a wide spectrum of activity against varies solid tumors, but it has serious side effects on nontumour cells. Cisplatin produces intra- and interstrand DNA cross-linking effects and chromosomal aberrations in mammalian cells. Vitamin $\mathrm{C}$ (ascorbic acid) is an antioxidant that can scavenge free radicals and protect cellular macromolecules, including DNA, from oxidative damage induced by different agents. Pretreatment administration of ascorbic acid on cisplatin induced chromosome aberrations has been determined in bone marrow cells of Swiss albino mice. Results showed that cisplatin $(7.5 \& 10 \mathrm{mg} / \mathrm{kg} \mathrm{bw}) \mathrm{IP}$ injection to male mice induced significant increase in the frequencies of chromosomal aberrations. The results of pre-treatment with ascorbic acid $(66 \mathrm{mg} / \mathrm{kg}$ bw) showed a significant decrease in the number of chromosomal aberrations induced with cisplatin tested doses. Ascorbic acid did not exhibit any clastogenic effect in male mice bone marrow cells. We concluded that ascorbic acid has a protective role against the genotoxicity induced by antitumor drug cisplatin.
\end{abstract}

Key words : Cisplatin- Antioxidants- Ascorbic Acid-Chromosomal Aberration- genotoxicity Bone Marrow Cells- Mice.

\section{Introduction}

Cisplatin (cis-diamminedichloroplatinum II) is an effective antitumor agent with a wide spectrum of activity against varies solid tumors, but it has serious side effects on nontumour cells, including free radical generation (Masuda et al.,1994). Cisplatin produces intra- and interstrand DNA cross-linking effects (Costa et al., 1996). This cytostatic induces chromosomal aberrations in cultured mammalian cells (Nefic, 2001) mouse bone marrow cells (Wiencke et al.,1979) and peripheral blood lymphocytes in patients (Osanto et al., 1991) and sister-chromatid exchanges in human lymphocytes in vitro (Wiencke et al.,1979 ; Bradley et al.,1979) and in vivo (Wiencke et al.,1979). The frequency of occurrence of cells with micronuclei is increased by cisplatin in human lymphocytes in vitro (Gebel et al.,1997 ; Nefic,
2001) and in erythrocytes in bone marrow cells of mice (Nakagawa et al.,1995). Identification and analysis of agents with anticlastogenic activity that reduce the frequency of chromosomal aberrations and possibility of practical application of natural protectors against the clastogenic (and mutagenic/ carcinogenic) action of chemical mutagens have a great importance ( Nefic, 2001). Ascorbic acid (AA) is an essential micronutrient for man, with many biological roles. It is a powerful antioxidant both directly via scavenging of reactive oxygen species and indirectly through regeneration of other antioxidant systems (Griffithsa and Lunecb, 2001). Many in vivo assays found that Vitamin $\mathrm{C}$ successfully reduced the clastogenic effects of many antitumour agents. Vitamin C inhibited tumor cell growth, binding of the 
active carcinogenic metabolite to cellular DNA (Gentile et al.,1998). As an antioxidant, Vitamin $\mathrm{C}$ may also have a potential anticancer activity, but its possible role and its mechanism of action in cancer prevention has not been clearly established ( Nefic, 2001). Therefore, the present study was undertaken to investigate the protective effects of Vitamin $\mathrm{C}$ on cisplatin induced chromosomal aberrations in mice bone marrow cells.

\section{Materials And Methods}

This experiment was carried out on male Swiss albino mice 10-12 weeks old and weighing approximately 30g.. Animals were kept and bred in an environmentaly controlled room with a temperature of $23 \pm$ 1. Chow and water were available ad. Libitum. Each experimental group was consisted of six animals for each treatment and control as shown in table (1).

Doses of cisplatin were selected on the basis of its effectiveness in inducing chromosomal aberration (Weijl et al., 1997). The dose of ascorbic acid was calculated according to the therapeutic dose and converted to mice according to Paget and Barner , (1967). Ascorbic acid was administered by gavage, $24 \mathrm{hrs}$ prior to the injection of IP single dose of cisplatin. Animals of control group were treated IP with saline in the same volume. All animals were injected IP with colchicines 2 hrs before sacrifice to arrest the cell division at metaphase.

\section{Scoring Of Slides}

Bone marrow preparation for the analysis of chromosomal aberrations in metaphase cells were obtained by Yosida and Amano (1965). One hundred metaphases per animal were analyzed in order to determine the frequencies of different chromosomal aberrations.

\section{Statistical Analysis}

Data of chromosomal aberrations examination were analyzed statistically using one way analysis of variance (ANOVA) according to Gupta (1995).

\section{Results}

The types of structural and numerical chromosomal aberrations induced by cisplatin and their frequencies in male mice bone marrow cells (at the concentration of 7.5 and $10 \mathrm{mg} / \mathrm{kg}$ body weight) in the absence and the presence of Vitamin $\mathrm{C}$ (at the concentrations of $66 \mathrm{mg} / \mathrm{kg}$ B.w.) are presented in Table (2) \& Fig. (1). Results showed that the treatment with Vitamin $\mathrm{C}$ alone at the tested concentration did not change the frequencies of chromosomal aberrations when compared with the untreated control. Intra-peritoneal injection with Cisplatin alone $7.5 \mathrm{mg} \& 10 \mathrm{mg} / \mathrm{kg}$ bw induced a statistically significant increase in the frequencies of total chromosomal aberrations $(P<0.001)$ when compared with control. The results also showed that Vitamin C pre-treatments significantly decreased the number of total chromosomal aberrations induced by Cisplatin $(P<0.001)$ in male mice bone marrow cells when compared with the animals treated with cisplatin alone. However, the number of these aberrations was not reduced to the control number of chromosomal aberrations as shown in Fig. (1).

Table (1): Experimental groups and treatment protocol.

\begin{tabular}{|l|l|l|}
\hline Treatments & Groups & Dose \\
\hline Control & I & vehicle only(dist. water) \\
\hline Ascorbic acid & II & $66 \mathrm{mg} / \mathrm{kg} \mathrm{b.w}$ \\
\hline Cisplatin & III & $7.5 \mathrm{mg} / \mathrm{kg} \mathrm{b} . \mathrm{w}$ \\
\hline Ascorbic acid + cisplatin & IV & $66 \mathrm{mg} / \mathrm{kg}+7.5 \mathrm{mg} / \mathrm{kg}$ b.w. \\
\hline Cisplatin $10 \mathrm{mg} / \mathrm{kg}$ & V & $10 \mathrm{mg} / \mathrm{kg} \mathrm{bw}$ \\
\hline Ascorbic acid + cisplatin & VI & $66 \mathrm{mg} / \mathrm{kg}+10 \mathrm{mg} / \mathrm{kg}$ bw \\
\hline
\end{tabular}


Table 2 : Frequencies of different chromosomal aberrations in male mice bone marrow cells of all experimental groups.

\begin{tabular}{|c|c|c|c|c|c|c|c|c|c|c|}
\hline \multirow[t]{2}{*}{ Groups } & \multicolumn{2}{|c|}{$\begin{array}{l}\text { Numerical } \\
\text { aberrations }\end{array}$} & \multicolumn{7}{|c|}{ Structural aberrations } & \multirow{2}{*}{$\begin{array}{c}\text { Total } \\
\text { aberrations }\end{array}$} \\
\hline & $2 n-$ & $2 n+$ & deletion & $\begin{array}{c}\text { Chromatid } \\
\text { gap }\end{array}$ & $\begin{array}{c}\text { Isochromatid } \\
\text { gap }\end{array}$ & $\begin{array}{c}\text { Chromatid } \\
\text { break }\end{array}$ & $\begin{array}{c}\text { Isochromatid } \\
\text { break }\end{array}$ & $\begin{array}{l}\text { Centromeric } \\
\text { attenuation }\end{array}$ & fragment & \\
\hline Control & $\begin{array}{c}0.50 \\
\pm \\
0.55\end{array}$ & $\begin{array}{c}0.00 \\
\pm \\
0.00\end{array}$ & $\begin{array}{c}0.50 \\
\pm \\
0.84\end{array}$ & $\begin{array}{c}2.67 \\
\pm \\
1.03\end{array}$ & $\begin{array}{c}0.50 \\
\pm \\
0.55\end{array}$ & $\begin{array}{c}1.17 .05 \\
\pm \\
0.41\end{array}$ & $\begin{array}{c}0.00 \\
\pm \\
0.00\end{array}$ & $\begin{array}{c}0.83 \\
\pm \\
0.75\end{array}$ & $\begin{array}{c}1.67 \\
\pm \\
0.52\end{array}$ & $\begin{array}{c}7.83 \\
\pm \\
2.14\end{array}$ \\
\hline $\begin{array}{c}\text { Ascorbic } \\
\text { acid }\end{array}$ & $\begin{array}{c}1.33 \\
\pm \\
1.20\end{array}$ & $\begin{array}{c}0.17 \\
\pm \\
0.41\end{array}$ & $\begin{array}{c}1.33 \\
\pm \\
0.82\end{array}$ & $\begin{array}{c}1.50 \\
\pm \\
1.05\end{array}$ & $\begin{array}{c}0.17 \\
\pm \\
0.41\end{array}$ & $\begin{array}{c}2.33 \\
\pm \\
1.03\end{array}$ & $\begin{array}{c}0.83 \\
\pm \\
0.75\end{array}$ & $\begin{array}{c}1.67 \\
\pm \\
1.03\end{array}$ & $\begin{array}{c}0.83 \\
\pm \\
0.75\end{array}$ & $\begin{array}{c}10.17 \\
\pm \\
1.60\end{array}$ \\
\hline $\begin{array}{c}7.5 \mathrm{mg} / \mathrm{kg} \\
\text { Cisplatin }\end{array}$ & $\begin{array}{c}1.17 \\
\pm \\
0.75\end{array}$ & $\begin{array}{c}0.33 \\
\pm \\
0.52\end{array}$ & $\begin{array}{c}2.17^{*} \\
\pm \\
0.75\end{array}$ & $\begin{array}{c}2.83 \\
\pm \\
1.60\end{array}$ & $\begin{array}{c}1.83^{*} \\
\pm \\
0.75\end{array}$ & $\begin{array}{c}1.67 \\
\pm \\
1.37\end{array}$ & $\begin{array}{c}1.33^{*} \\
\pm \\
0.82\end{array}$ & $\begin{array}{c}0.83 \\
\pm \\
0.75\end{array}$ & $\begin{array}{c}1.83 \\
\pm \\
0.76\end{array}$ & $\begin{array}{c}14.00^{* *} \\
\pm \\
2.83\end{array}$ \\
\hline $\begin{array}{c}\text { Ascorbic } \\
\text { acid + } \\
7.5 \mathrm{mg} / \mathrm{kg} \\
\text { Cisplatin }\end{array}$ & $\begin{array}{c}1.00 \\
\pm \\
0.63\end{array}$ & $\begin{array}{c}0.17 \\
\pm \\
0.41\end{array}$ & $\begin{array}{c}0.17 \\
\pm \\
0.41\end{array}$ & $\begin{array}{c}2.33 \\
\pm \\
1.03\end{array}$ & $\begin{array}{c}0.17 \\
\pm \\
0.41\end{array}$ & $\begin{array}{c}2.33 \\
\pm \\
1.03\end{array}$ & $\begin{array}{c}0.17 \\
\pm \\
0.41\end{array}$ & $\begin{array}{c}2.33^{*} \\
\pm \\
1.21\end{array}$ & $\begin{array}{c}1,50 \\
\pm \\
1,05\end{array}$ & $\begin{array}{c}10.17 \\
\pm \\
2.40\end{array}$ \\
\hline $\begin{array}{c}10 \mathrm{mg} / \mathrm{kg} \\
\text { Cisplatin }\end{array}$ & $\begin{array}{c}1.00 \\
\pm \\
0.63\end{array}$ & $\begin{array}{c}0.50 \\
\pm \\
0.55\end{array}$ & $\begin{array}{c}2.30^{*} \\
\pm \\
1.37\end{array}$ & $\begin{array}{c}2.83 \\
\pm \\
1.94\end{array}$ & $\begin{array}{c}1.00^{*} \\
\pm \\
0.89\end{array}$ & $\begin{array}{c}2.30 \\
\pm \\
0.52\end{array}$ & $\begin{array}{c}0.33 \\
\pm \\
0.52\end{array}$ & $\begin{array}{c}3.00^{* *} \\
\pm \\
1.79\end{array}$ & $\begin{array}{c}2.00 \\
\pm \\
0.89\end{array}$ & $\begin{array}{c}15.33^{* *} \\
\pm 2.25\end{array}$ \\
\hline $\begin{array}{c}\text { Ascorbic } \\
\text { acid+ } \\
10 \mathrm{mg} / \mathrm{kg} \\
\text { Cisplatin }\end{array}$ & $\begin{array}{c}1.00 \\
\pm \\
0.63\end{array}$ & $\begin{array}{c}0.17 \\
\pm \\
0.41\end{array}$ & $\begin{array}{c}1.33 \\
\pm \\
0.52\end{array}$ & $\begin{array}{c}2.83 \\
\pm \\
0.98\end{array}$ & $\begin{array}{c}1.50^{*} \\
\pm \\
0.55\end{array}$ & $\begin{array}{c}2.00 \\
\pm \\
1.41\end{array}$ & $\begin{array}{c}1.33^{*} \\
\pm \\
0.82\end{array}$ & $\begin{array}{c}0.83 \\
\pm \\
0.98\end{array}$ & $\begin{array}{c}1.00 \\
\pm \\
1.26\end{array}$ & $\begin{array}{c}12.00^{* *} \\
\pm \\
2.37\end{array}$ \\
\hline
\end{tabular}

Data represent the mean \pm standard error of each chromosomal aberrations in six animals.

* statistically significant at $\mathrm{p} \leq 0.05$.

$* *$ statistically significant at $\mathrm{p} \leq 0.01$.

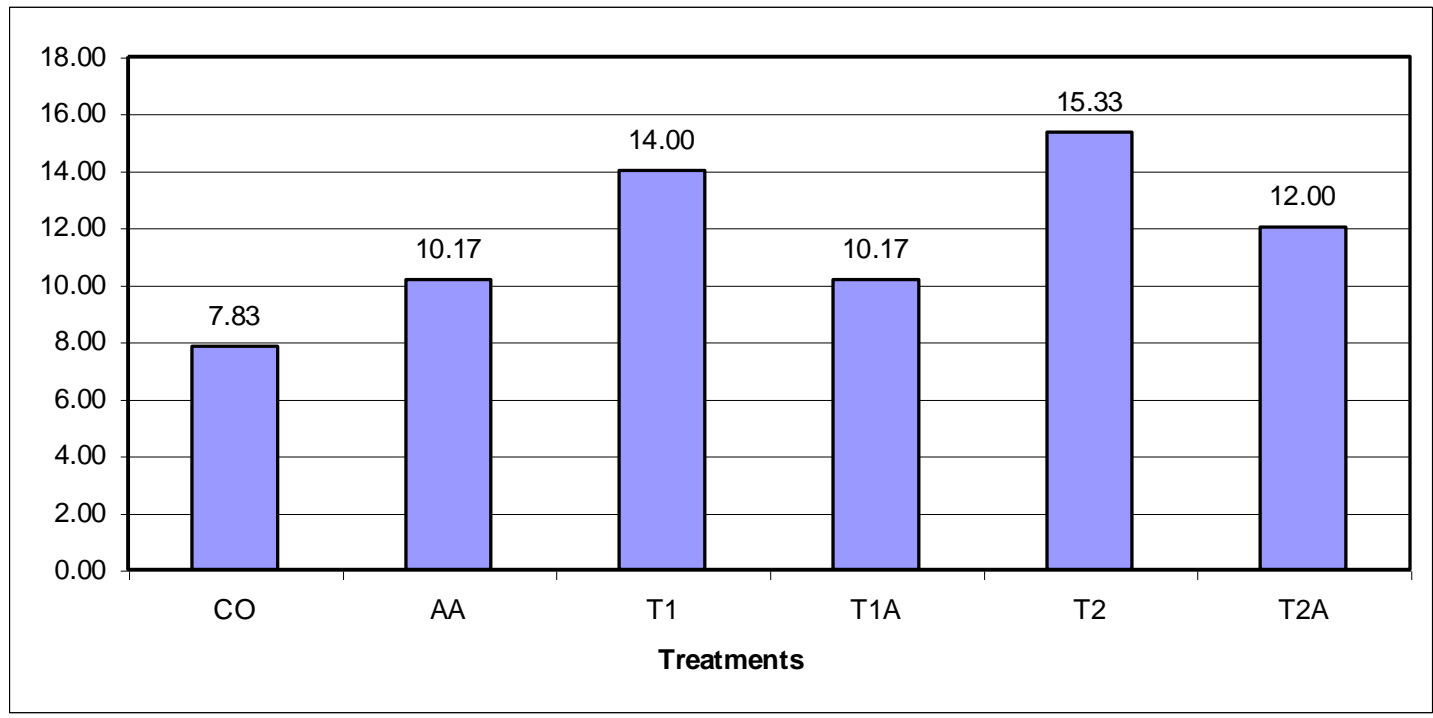

Fig. (1): Histogram Showing the reduction in cisplatin induced genotoxic damage in presence of ascorbic acid. 


\begin{tabular}{|c|c|}
\hline CO & Control \\
\hline AA & Ascorbic Acid \\
\hline T1A & Cisplatim 7.5 mg+ Ascorbic Acid 66 mg \\
\hline T1 & Cisplatim 7.5 mg \\
\hline T2A & Cisplatim 10 mg+ Ascorbic Acid 66 mg \\
\hline T2 & Cisplatim 7.5 mg \\
\hline
\end{tabular}

\section{Discussion}

The use of natural dietary antioxidants to prevent antitumor agents -induced chromosomal damage is currently eliciting considerable interest. Antitumor agents are known to interact with specific biological molecules, and evidence has been obtained that treatment with antitumor drugs from different categories leads to generation of free radicals in nontumor cells both in vivo and in vitro ( Weijl et al.,1997). Cisplatin is an effective antitumour drug but it has serious side effects on non tumour cells, including free radical generation (Masuda et al., 1994). Cisplatin produces intra- and interstrand DNA cross-linking effects (Costa et al., 1996). This cytostatic drug induces chromosomal aberrations in cultured mammalian cells (Nefic, 2001), mouse bone marrow cells (Wiencke et al., 1979) and peripheral blood lymphocytes in patients (Osanto et al., 1991) and sisterchromatid exchanges in human lymphocytes in vitro and in vivo (Bradley et al., 1979). The frequency of occurrence of cells with micronuclei is increased by cisplatin in human lymphocytes in vitro (Gebel et al., 1997) and in erythrocytes in bone marrow cells of mice (Nakagawa et al., 1995). Results of the present study markedly showed that a single IP injection of both doses $(7.5$ and $10 \mathrm{mg} / \mathrm{kg}$ body weight) of Cisplatin significantly increased the frequencies of chromosomal aberrations in mice bone marrow cells. The chromo-somal aberrations pattern revealed that chromatid breaks and gaps occurred more frequently. However, the results of pre-treatment with Vitamin $\mathrm{C}$ indicated that the number of aberrant metaphases induced by cisplatin in mice bone marrow cells were statistically significantly decreased. Vitamin C shows most efficient anticlast-ogenic effect in the treatments with cisplatin. This result was in agreement with (Giri et al., 1998) they suggested that vitamin $\mathrm{C}$ has a definite protective role on chromosomal aberrations and micronucle formation induced by cisplatin. Vitamin $\mathrm{C}$ also has in vivo anticlastogenic effects against chromosomal damage and number of abnormal metaphases induced by cisplatin in rodents (Gentile et al., 1998; Antunes et al., 2000). Vitamin C successfully reduces the clastogenic effect of many other antitumour drugs like cyclophosphamide (Ghaskadbi et al., 1992), doxorubicin (Antunes and Takahashi, 1998, 1999) and bleomycin (Anderson et al., 1994 \& 1995). Also, Vitamin $\mathrm{C}$ reduces the chromosomal aberrations induced by trenimon (Gebhart, 1984), H2O2 (Dallapiccola, 1985), ethyl methanesulfonate (Kuroda, 1987; Kojima, et al., 1992), levodopa, noradrenalin and dopamine (Iwawaki, et al., 1988) and pesticides (Khan and Sinha, 1993) and sister chromatid exchanges (SCEs) induced by cyclophosphamide, mitomycin $\mathrm{C}$ (Krishna et al., 1986), thiotepa, l-ethionine (Lialiaris et al., 1987). Odin (1997) showed that continual oral consumption of large amounts of Vitamin $\mathrm{C}$ for a long period is able to significantly decrease the number of chromosomal breaks induced in human lymphocytes by various xenobiotics. Similar results were obtained by Duthie et al. (1996). They showed that supplementation of the diet with Vitamin C results in a highly significant decrease in 
endogenous oxidative base damage in the DNA of lymphocytes of patients, and lymphocytes of antioxidant-supplemented subjects showed an increased resistance to oxidative damage in vitro. The protective role of Vitamin $\mathrm{C}$ observed here suggests that Vitamin $\mathrm{C}$ has an antioxidative effect on damage induced by free radicals generated during the metabolic activity of cisplatin in mice bone marrow cells. Thus, the present study clearly indicates the protective role of vitamin $\mathrm{C}$ against cisplatin induced genotoxicity.

\section{References}

1. Anderson, D.; Basaran, N.; Blowers, S.D and Edwards, A.J. (1995): The effect of antioxidants on bleomycin treatment in vitro and in vivo genotoxicity assays. Mutat. Res. 329 : 37-47.

2. Anderson, D.; Yu,T. W. ; Phillips, B.J. and Schmezer, P. (1994) : The effect of various antioxidants and other modifying agents on oxygen-radical-generated DNA damage in human lymphocytes in the COMET assay. Mutat. Res. 307 : 261-271.

3. Antunes, L.M.G. and Takahashi, C.S. (1998) : Effects of high doses of Vitamins $\mathrm{C}$ and $\mathrm{E}$ against doxorubicin -induced chromosomal damage in Wistar rat bone marrow cells, Mutat. Res. 419 : 137-143.

4. Antunes, L.M.G. and Takahashi, C.S. (1999) : Protection and induction of chromosomal damage by Vitamin $\mathrm{C}$ in human lymphocyte cultures, Teratogen. Carcinogen. Mutagenen. 19: 53-59.

5. Antunes, L.M.G. Araújo, M.C.P; Darin, J.D.C.and Bianchi, M.L.P(2000) : Effects of the antioxidants curcumin and Vitamin $\mathrm{C}$ on cisplatin-induced clastogenesis in Wistar rat bone marrow cells. Mut. Res. 465 : 131137.

6. Bradley, M.O. Hsu, I.C. and Harris, C.C. (1979) : Relationships between sister-chro- matid exchange and mutagenicity, toxicity and DNA damage. Nature 282: 318-320.

7. Costa, M.; Zhitkovich A.; Gargas M.; Paustenbach, D.; Finley, B. ;Kuykendall, J.; Billings, R.; Carlson, T.J.; Wetterhahn, K.; Xu, J.; Patierno, S. and Bogdanffy, M. (1996) : Interlaboratory validation of a new assay for DNA-protein cross-links. Mutat. Res. 369 : 13-21.

8. Dallapiccola, B.; Porfiro, B.; Mokini, V. ; Alimena, G.; Isacchi, G. and Gandini, E. (1985) : Effect of oxidants and antioxidants on chromosomal breakage in Fanconi ane-mia lymphocytes. Hum.Genet. 69 : 62-65.

9. Duthie, S.J. ; Ma, A.; Ross, M.A. and Collins, A.R. (1996): Antioxidant supplementation decreases oxidative DNA damage in human lymphocytes. Cancer Res. 56 : 1291-1295.

10. Gebel, T.; Lantzsch, H.; Ple_O. W. K. and Dunkelberg, H. (1997) : Genotoxicity of platinum and palladium compounds in human and bacterial cells. Mutat. Res. 389 : 183-190.

11. Gebhart, E. (1984) : The action of antimutagens on chemically induced SCE, Basic Life Sci. 29A : 319-322.

12. Gentile, J.M. ; Rahimi, S.; Zwiesler, J. ; Gentile, G.J..and Ferguson, L.R (1998) : Effect of selected antimutagens on the genotoxicity of antitumour agents. Mutat. Res. 402 : 289-298.

13. Ghaskadbi, S.; Rajmachikar, S.; Agate, C.; Kapadi, A.H. and Vaidya,V.G (1992): Modulation of cyclophosphamide mutageni-city by Vitamin $\mathrm{C}$ in the in vivo rodent micronucleus assay. Teratogen. Carcinogen. Mutagenen. 12 : 1117.

14. Giri, A.; Khynriam, D. and Prasad, S.B. (1998) : Vitamin C medited protection on cisplatininduced mutagenicity in mice. Mutat. Res. 421: 139-148. 
15. Griffithsa , H.R. and Lunecb, J. (2001) : Ascorbic acid in the $21 \mathrm{st}$ century - more than a simple antioxidant Environmental Toxicology and Pharmacology. 10 (4): 173 $-182$.

16. Gupta, S.P.(1995) : Statistics methods,New Delhi, Sultan Chand and Sons.A.5.19-A5.28. Iwawaki, H.; Ito, M.; Kogiso, S. and Yoshitake, A. (1988) : Effects of 1ascorbic acid on the clastogenicity of catecholamines, Mutat. Res. 203 : 374.

17. Khan, P.K. and Sinha, S.P. (1993) : Antimutagenic efficacy of higher doses of Vitamin C. Mutat. Res. 298 : 157-161.

18. Kojima, H. l ; Konishi, H. and Kuroda, Y. (1992) : Effects of 1ascorbic acid on the mutagenicity of ethyl methanesulfonate in cultured mammalian cells. Mutat. Res. 266 : 85-91.

19. Krishna, G.; Nath, J. and Ong, T. (1986) : Inhibition of cyclophosphamide and mitomycin C-induced sister chromatid exchanges in mice by Vitamin $\mathrm{C}$. Cancer Res. 46 : 2670-2674.

20. Kuroda, Y. (1987) : Antimutagenic mech-anism of Vitamin $\mathrm{C}$ and its derivatives in mammalian cells in culture. Mutat. Res. $182: 365$.

21. Lialiaris, T. ; Mourelatos, D. and Dozi-Vassiliades, J. (1987) : Enhancement and attenuation of cytogenetic damage by Vitamin $\mathrm{C}$ in cultured human lymphocytes exposed to Thiotepa or 1-ethionine. Cytogenet. Cell Genet. 44 : 209214.

22. Masuda, H.; Tanaka, T. and Takahama, U. (1994) : Cisplatin generates superoxide anion by interaction with DNA in a cell-free system. Biochem. Biophys. Res. Commun. 203: 1175-1180.
23. Nakagawa, I.; Nishi, E.; Naganuma, A. and Imura, N. (1995) : Effect of preinduction of metallothionein synthesis on clastogenicity of anticancer drugs in mice. Mutat. Res. 348 : 37-43.

24. Nefic, H. (2001) : Anticlastogenic effect of Vitamin $\mathrm{C}$ on cisplatin induced chromosome aberrations in human lymphocyte cultures. Mutation Research 498 : 89-98.

25. Paget ,G.E. Aand Barners, J.M .(1964): Pharmacometrics :E valuation of drug activities.$^{\text {st }}$ ed ., Laurence Acad. Press, London and new york.p.220.

26. Odin, A.P. (1997) : Vitamins as antimutagens: advantages and some possible mechanisms of antimutagenic action. Mutat. Res.386 : 39-67.

27. Osanto, S.; Thijssen, J.C.P ; Woldering, V.M.; van Rijn, J.L.S ; Natarajan, A.T. and Tates, A.D. (1991) : Increased frequency of chromosomal damage in peripheral blood lymphocytes up to nine years following curative chemotherapy of patients with testicular carcinoma. Environ. Mol. Mutagen. 17 : 7178.

28. Weijl, N.I. ; Cleton, F.J. and Osanto, S. (1997) : Free radicals and antioxidants in chemotherapyinduced toxicity. CancerTreat.Rev.23:209-240.

29. Wiencke, J.K.; Cervenka, J. and Paulus, H. (1979) : Mutagenic activity of anticancer agent cisdichlorodiammine platinum-II. Mutat.Res. 68 : 69-77.

30. Yosida,T.H. and Amano, K.(1965): Autosomal polymorphism in laboratory bred and Wild Norway rats. Rattus norvegicus found in Misima. Chromosoma., 16:658-667. 


\title{
التأثير الوقائي لحمض الاسكوربيك على السمية الوراثية لعقار السيسبلاتين

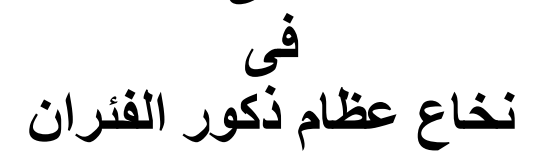

\author{
نداى النواتى \\ قسم البيولوجى - جامعة الملك عبدالعزيز
}

تهذف هذه الدر اسـة إلى توضيح دور حمض الاسكوربيك فى الوقايـة من التأثير ات

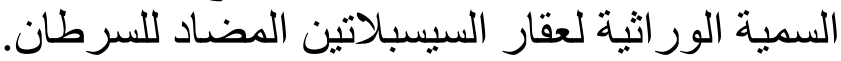

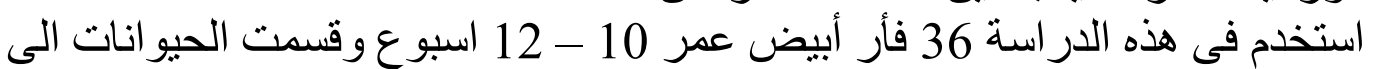

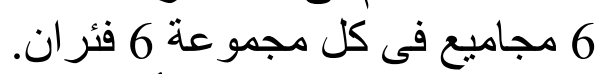

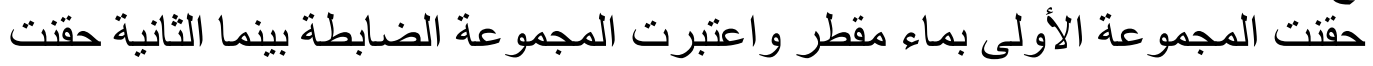

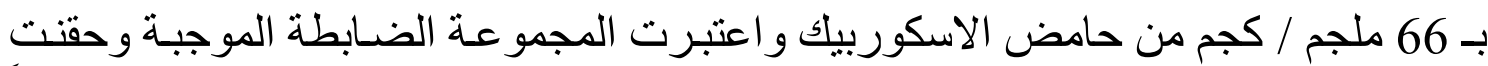

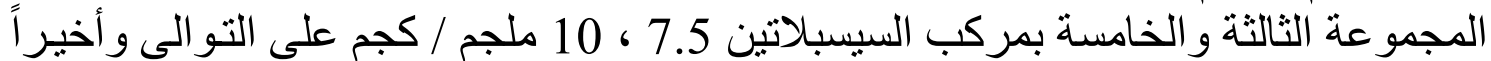

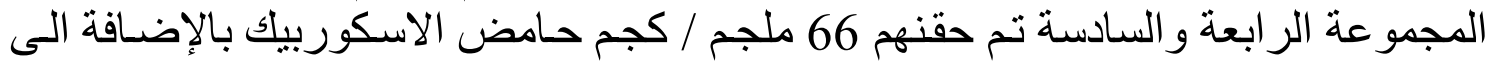
7.5 ، 10 ملجم سيسبلاتين على التو والتو الى الى. وقد أوضحت النتائج المتحصل على التيها التأثير الو اقى لحامض الاسكوربيك على التى السمية

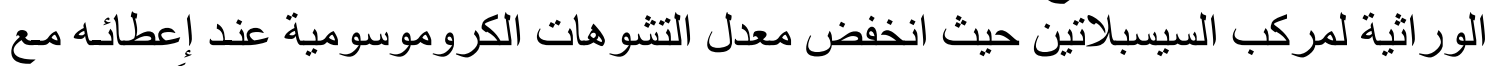

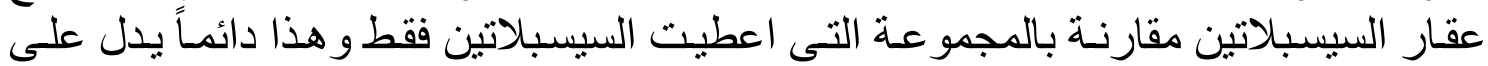
التأثير الو اقى ضد التشوهات الكروموسومية لحمض الاسكوربيك فى خلايا نخاع العظام. 